\title{
A New Hybrid Material for the Removal of Cu(II) and Co(II) Ions from Aqueous Solutions
}

\author{
Sulu Çözeltilerden Cu(II) ve Co(II) Uzaklaştırılması için Yeni bir \\ Hibrit Materyal
}

\author{
Research Article \\ Muharrem Karabörk' ${ }^{*}$ and Idrees Salim Khalo \\ 'Department of Chemistry, Kahramanmaraş Sütçü Imam University, Kahramanmaraş, Turkey. \\ 2Department of Material Science and Engineering, Kahramanmaraş Sütçü Imam University, Kahramanmaraş, Turkey.
}

\section{A B S T R A C T}

I this study, a new multi-walled carbon nanotube(MWCNT) based hybrid material was obtained and used as adsorbent for the removal of $\mathrm{Cu}(\mathrm{II})$ and $\mathrm{Co}(\mathrm{II})$ from aqueous solutions. In the synthesis, firstly, the surface of MWCNT was modified via Hummer method to give oxidized MWCNT-O. In the following step, the oxidized MWCNT was treated with 3-aminopropyl triethoxysilane (APTES) to give a silanized form of MWCNT having free amine end groups. Finally, the silanized MWCNT was reacted with 3,5-dichlorosalicylaldehyde to give the hybrid material. The new hybrid material was characterized by analytical and spectroscopic methods (FT-IR, UV-Vis., TGA, Raman Spectra, SEM, TEM, EDX and XRD studies). The hybrid material was used as adsorbent for the removal of $\mathrm{Cu}(\mathrm{II})$ and $\mathrm{Co}(\mathrm{II})$ ions from aqueous solutions. The effects of adsorption parameters such as $\mathrm{pH}$, contact time, temperature, and initial concentrations on adsorption behaviors were investigated.

\section{Key Words}

Multi-walled carbon nanotube, Hybrid material, Cu(II)-Co(II), Adsorption behavior.

\section{öz}

u çalışmada, çok duvarlı karbon nanotüp (MWCNT) temelli yeni hybrid material sentezlenmiştir. Sentezlenen hybrid materyal sulu ortamdan $\mathrm{Cu}(\mathrm{II})$ ve Co(II) uzaklaştımak için adsorbent olarak kullanılmıştır. Hibrid materyal üç aşamada sentezlenmiştir. Birinci aşamada Hummer metodu kullanılarak çok duvarlı karbon nanotüp okside (MWCNT-O) edilmiştir. Sonraki aşamada okside edilen karbon nanotüp 3-aminopropiltrietoksisilan ile muamele edilerek serbet - $\mathrm{NH} 2$ gruplarına sahip silanlanmış karbon nanotüp elde edilmiştir. Son aşamada ise silanlanmış karbon nanotüp 3,5-diklorosalisilaldehit ile tepkimesinden hybrid malzeme elde edilmiştir. Sentezlenen hybrid malzeme analtik ve spektroskopik yöntemlerle karakterize edilmiştir (FT-IR, Uv-vis, TGA, Raman, SEM, TEM, EDX ve XRD çalışmaları ile). Hibrid malzeme sulu ortamdan Cu(II) veya Co(II) iyonlarının uzaklaştırılmasında adsorbent olarak kullanılmıştır. Hibrid malzemenin adsorpsiyon kapasitesi üzerine pH, temas süresi, başlangıç konsantrasyon ve sıcaklık parametreleri incelenmiştir.

\section{Anahtar Kelimeler}

Çok duvarlı karbon nanotüp, Hibrid materyal, Cu(II)-Co(II), Adsorpsiyon özellikleri.

Article History: Received: May 8, 2018; Revised: May 29, 2018; Accepted: Jul 6, 2018; Available Online: Oct 4, 2018.

DOI: 10.15671/HJBC.2018.248

Correspondence to: M. Karabörk, Department of Chemistry, Kahramanmaraş Sütçü Imam University, Kahramanmaraş, Turkey. 


\section{INTRODUCTION}

C nvironmental pollution of air, water and - land is a popular issue due to its harms or discomfort to humans or other living organisms. Pollutions are mainly caused by human activities like agricultural such as pesticides, sewage, fuel combustion in cars and other motors, factories include chemical plants and production of plastics etc. [1]. Water pollution is one of the most important problems in most countries of the world and it was reported that water contamination is one of the main reasons of deaths and diseases [2]. Every day more than 14.000 people die due to water pollution related diseases $[3,4]$. The water contamination due to the heavy metal ions is also worldwide concern. Waste water must be treated to protect clean water, before discharge back to the environment for reuse as drinking and for various other purposes, including medical needs, pharmacy, chemicals and industrial applications. There are many ways of pollutants discharged from households and manufacturing processes to the environment. These contaminants are toxic gases (sulfur oxides, nitrogen oxides, carbon monoxide and so on), organic/inorganic compounds (hydrocarbons and arsenic) and heavy metals (mainly transition metals). Most heavy metals are trace elements and crucial roles in living organisms, however, they have toxic effects on living beings at above certain concentration [5]. Heavy metal ions are not biodegradable [6] and these metal ions including zinc(Zn), cadmium, lead, nickel, copper, mercury, chromium, iron and cobalt are the most frequently found in industrial wastewaters [7].

Copper is hard, flexible and highly conductive metal and one of the world's most import significant metals. It is found as a pure metal in nature, and this was the first source of the metal to be used by humans. Copper is a very big recycling metal, about $90 \%$ of copper scrap is recycled. The biological role of copper, in humans and animals found as a trace element have several roles in the health of all living things, mostly in the liver, muscle, and bone [8]. $\mathrm{Cu}(\mathrm{II})$ ion found in the active active site of several enzymes. Although copper has a significant role for the biological systems, the excess amount of copper ion in living organisms shows toxic effects. Cobalt is lustrous, silvery-blue metal hard and magnetic. It's often associated with nickel, silver, lead, copper and iron ores; it is most much obtained as a by-product of other metals like copper. Cobalt is component of Vitamin $B_{12}$ in many living, also is widely used in batteries, electroplating, blue and green colors in glass and ceramics, radioactive ${ }^{60} \mathrm{Co}$ is used in the treatment of cancer $[9,10]$.

Over the last few decades Carbon Nanotubes (CNTs) have attracted considerable interest due to their unique physical and chemical properties, for example, they have been used as an adsorbent for the removal of heavy metal ions from different environmental contaminants [11]. In continuation of our interest in nanomaterial design for the removal of heavy metal ions from waste waters, we prepared a new hybrid material based on multiwalled carbon nanotubes. The new material was characterized by FT-IR, Uv-Vis, Raman Spectra, TGA, SEM, TEM, and EDX analysis. The hybrid material was then used in solid phase extractions of $\mathrm{CU}$ (II) and $\mathrm{Co}$ (II) ions from aqueous solutions. The adsorption parameters such as $\mathrm{pH}$, contact time, temperature, and initial concentrations for the removal of metal ions were investigated in detail to determine the optimum conditions.

\section{MATERIALS and METHODS Chemicals}

All chemicals and solvents were used in high purity and used as received without further treatment. Multi-walled Carbon nanotube (MWCNTs), nitric acid, sulfuric acid, hydrogen peroxide, amino propyl (3-triethoxsilyl propylamine), 3, 5-dichloro salicylicaldehyde were purchased from Sigma-Aldrich. Copper(II) acetate monohydrate $\left(\mathrm{Cu}\left(\mathrm{CH}_{3} \mathrm{COO}\right)_{2} \cdot \mathrm{H}_{2} \mathrm{O}\right)$ and Cobalt(II) nitrate hexahydrate $\mathrm{Co}\left(\mathrm{NO}_{3}\right)_{2} \cdot 6 \mathrm{H}_{2} \mathrm{O}$ (from Merck, Darmstadt, Germany) were used to prepare standard metal ion solutions.

\section{Characterization}

Infrared spectra were obtained using $\mathrm{KBr}$ disc (4000-400 $\mathrm{cm}^{-1}$ ) on a Perkin Elmer Paragon 1000 PC (Waltham, MA, USA). The electronic spectra in the 200-900 $\mathrm{nm}$ range were obtained on a Perkin Elmer Lambda 45 spectrophotometer (Waltham, MA, USA). The thermal studies of the compounds were performed on a Perkin Elmer STA 6000 simultaneous Thermal Analyzer under nitrogen atmosphere at a heating rate of $10^{\circ} \mathrm{C} /$ min (USA). The quantity of the $\mathrm{Cu}(\mathrm{II})$ and $\mathrm{Co}(\mathrm{II})$ 
ions obtained from the aqueous solutions was determined by Inductive Coupled Plasma-Optical Emission Spectrometer (ICP-OES) (Perkin Elmer Brand Optima 2100 DV) (Waltham, MA, USA). All experimental conditions were kept the same for all samples. X-ray diffraction (XRD) patterns were conducted on a Philips X'Pert Pro X-ray diffractometer (XRD) (Netherlands), with $\mathrm{Cu}$ $\mathrm{K} \alpha$ radiation. Scanning range was $5-100^{\circ}$ and was taken as 2 . The surface morphologies and microstructures of the samples were studied by a scanning electron microscope (SEM, EVOLS10 Zeiss, Jena, Germany) and a transmission electron microscope (TEM, JEOL JEM2010, Peabody, MI, USA), respectively. The surface morphology and EDX analysis of the nanocomposite ligands and the complexes were analyzed using Zeiss Evo LS10 SEM attached with Bruker Quantax EDS (Germany). Hanna HI 2211-05 desktop pH meter (Michigan, USA) was used for $\mathrm{pH}$ adjustments of the solutions.

\section{Synthesis of Oxidized Multi-walled Carbon Nanotube (MWCNT-O)}

Pristine multi-walled carbon nanotube (MWCNT) was used as starting material for the preparation of oxidized MWCNT. The surface of MWCNT was oxidized according to the Hummers method [12]. The multi-walled carbon nanotube (MWCNT) (3 g) was dispersed in nitric acid and stirring for $48 \mathrm{~h}$. After that, the material was filtered and washed with water until $\mathrm{pH}$ of filtrate is about 7 . The material was then treated with sulfuric acid and hydrogen peroxide in the ratio 70:30. The reaction mixture was stirred for $24 \mathrm{~h}$ and diluted with water. The product was filtered and washed with plenty of water until the filtrate $\mathrm{pH}$ is about neutral. The product was then dried in oven at 40 ${ }^{\circ} \mathrm{C}$.

\section{Synthesis of Silanized Multi-walled Carbon Nanotube (APTES-MWCNT)}

The silanization of oxidized MWCNT-O was conducted according to the reported method [13]. The oxidized MWCNT $(0.025 \mathrm{~g})$ was dispersed in toluene $(30 \mathrm{~mL})$ and stirred for $1 \mathrm{~h}$. To the stirring mixture, (3-aminopropyl) triethoxysilane (APTES) $(2 \mathrm{~mL}$ ) was added and reaction mixture was refluxed for $48 \mathrm{~h}$. The reaction mixture was cooled down to the room temperature and the silanized product was washed with ethanol and water. The final product was then dried in an oven at $80^{\circ} \mathrm{C}$.

\section{Synthesis of Hybrid Material (HM)}

The hybrid material (HM) was obtained from a Schiff base condensation reaction of silanized MWCNT (APTES-MWCNT) and 3,5-dichlorosalicyaldehyde. APTES-MWCNT $(0.7 \mathrm{~g})$ and 3, 5-dichloro-salicyaldehyde $(0.7 \mathrm{~g})$ were mixed in ethanol $(150 \mathrm{~mL})$. The reaction solution was refluxed for $72 \mathrm{~h}$. Upon cooling to the room temperature, the hybrid material was filtered, washed with ethanol and dried in air.

\section{RESULTS and DISCUSSION}

In this work, a new hybrid material (HM) was prepared and used an adsorbent for the removal of $\mathrm{Cu}(\mathrm{II})$ and $\mathrm{Co}(\mathrm{II})$ ions from aqueous solutions. The material was prepared in three step reactions. In the first step, multi-walled carbon nanotube (MWCNT) was oxidized according to the Hummer's method to give oxidized (MWCNT-O). In the following step, oxidized MWCNT-O was treated with 3-aminopropyl) triethoxysilane to give silanized carbon nanotube (APTES-MWCNT) having free primer amine end groups. In the final step, the free amine groups of silanized carbon nanotube (APTES-MWCNT) was reacted with an aldehyde compound (3,5-dichlorosalicylaldehyde) resulting in a new hybrid material. The synthesis of the new hybrid material was shown in Figure 1.

UV-Vis. electronic spectrum of the oxidized multi-walled carbon nanotube (MWCNT-O) was studied in water. In the spectrum (Figure 2), there are two characteristic absorption bands at 230 and $263 \mathrm{~nm}$. The absorption band at $230 \mathrm{~nm}$ is due to the characteristic electronic transitions from the ground state orbital to a high energy state $(\pi-\pi *$ transition) due to $\mathrm{C}=\mathrm{C}$ double bond. The absorption band at $263 \mathrm{~nm}$ with lower intensity is assigned to the electronic transition between the non-bonding orbital to a high energy state orbital ( $v-\pi *$ transition) due to $\mathrm{n}$ electrons of the carboxyl $(-\mathrm{COOH})$ or hydroxyl groups. The $v-\pi *$ transition confirms the oxidation on the surface of the multi-walled carbon nanotube [14].

FT-IR spectra of the MWCNT-O, APTES-MWCNT and hybrid material (HM) were taken to determine 

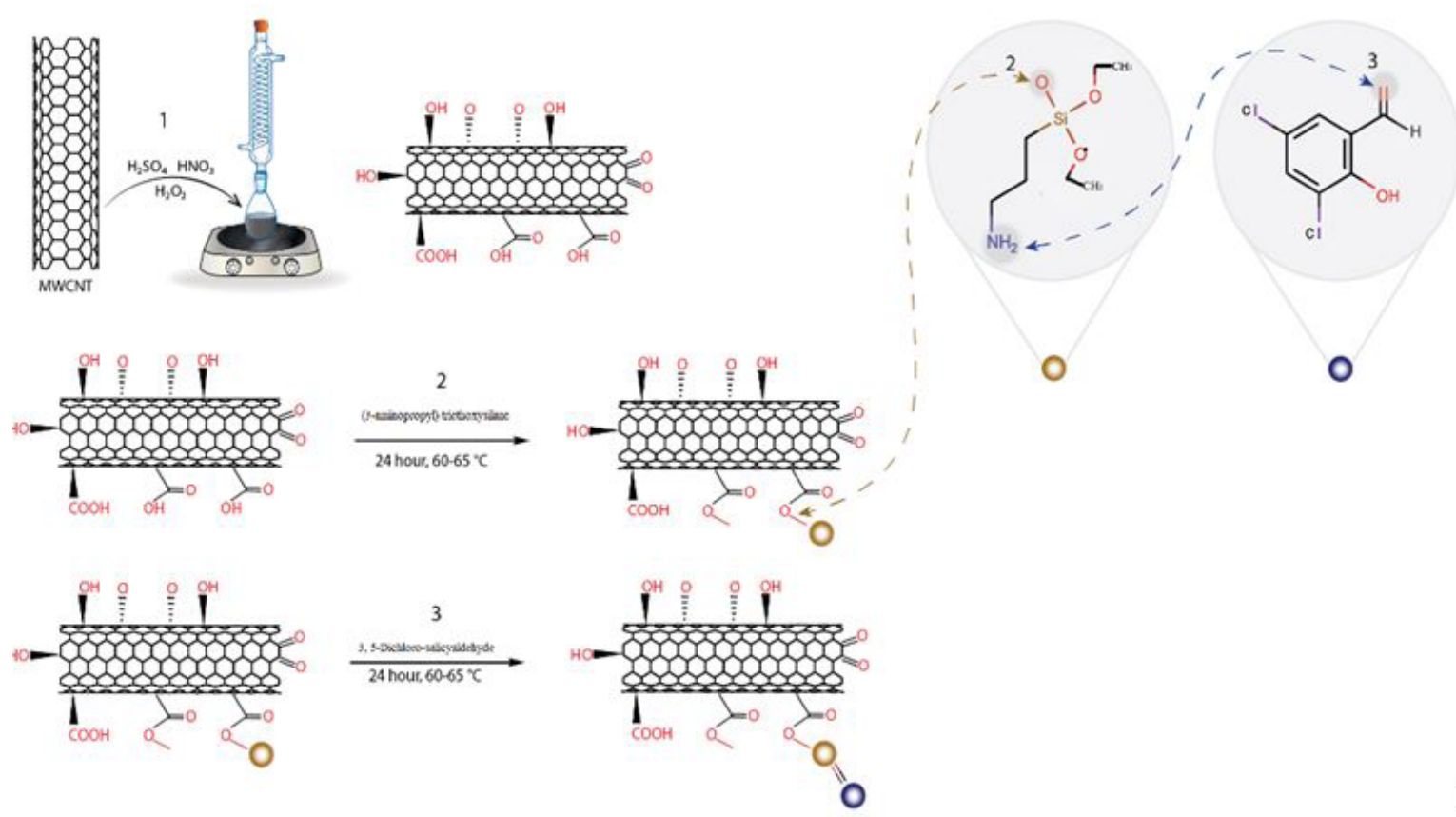

Figure 1. Synthesis of the hybrid material (HM).

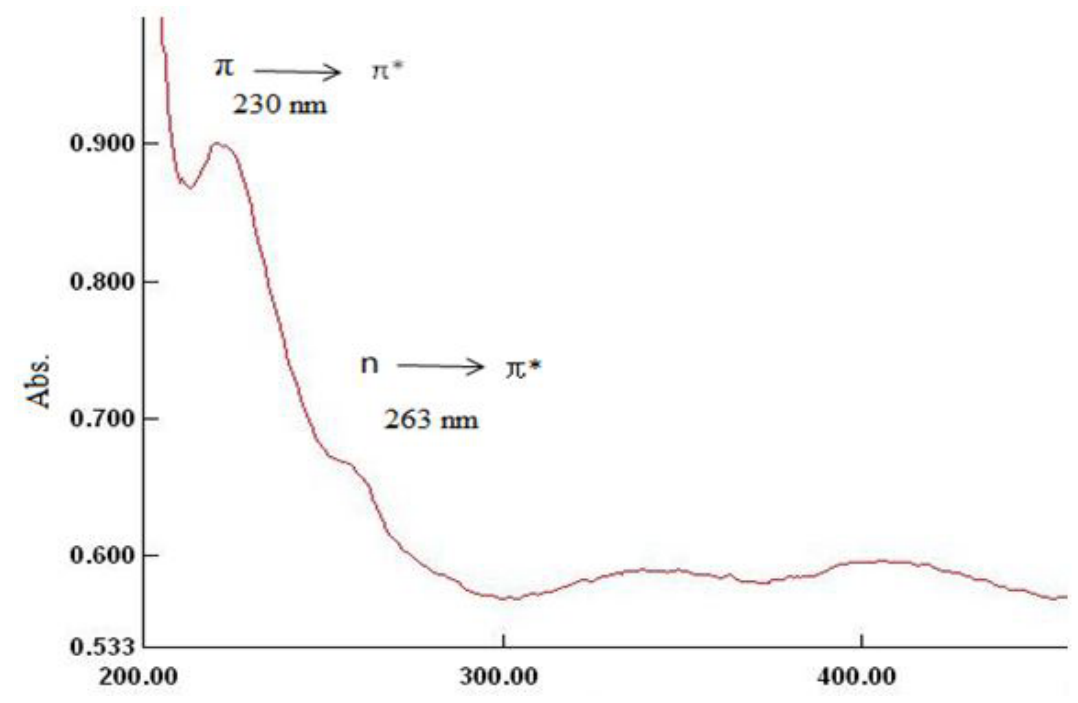

Figure 2. UV-Vis. spectrum of MWCNTs-O.

the characteristic vibrational frequencies in the samples. FT-IR spectra of the MWCNT-O, APTESMWCNT and hybrid material (HM) is given in Figure 3. FT-IR spectrum of MWCNT-O shows stretching peaks at $3435.68,1737.19$ and $1628.98 \mathrm{~cm}^{-1}$, which are assigned to the $v(\mathrm{OH}), v(\mathrm{C}=0)$, and $v(\mathrm{C}=\mathrm{C})$ vibrations, respectively [15]. The peak at 3435.68 $\mathrm{cm}^{-1}$ is attributed to the stretching vibrations of $\mathrm{O}-\mathrm{H}$ groups $(-\mathrm{COOH}$ and $-\mathrm{COH})$, and a peak at 1381.64 $\mathrm{cm}^{-1}$ is $\mathrm{O}-\mathrm{H}$ due to the in-plane bending vibration deformations of $-\mathrm{COOH}$ groups $[16,17]$. The band at $1116.90 \mathrm{~cm}^{-1}$ corresponds to $v(\mathrm{C}-\mathrm{O})$ stretching of carboxylic groups [18-21]. The spectrum also shows the peak at $1628.98 \mathrm{~cm}^{-1}$ which is assigned to the conjugated carbonyl $\mathrm{C}=\mathrm{C}$ stretching [22].

The FT-IR spectrum of APTES-MWCNT showed a band at $3426.94 \mathrm{~cm}^{-1}$ assigned to the stretching vibrations $v\left(\mathrm{NH}_{2}\right)$ [23]. The bands at 2922.20 and $2853.88 \mathrm{~cm}^{-1}$ correspond to stretching of symmetric/asymmetric methylene groups $(v(\mathrm{C}-\mathrm{H}))$. The carboxyl group stretchings $v(\mathrm{COOH})$ are disappeared in the spectrum of APTES-MWCNT which confirms the silanization of MWCNT [24]. In 


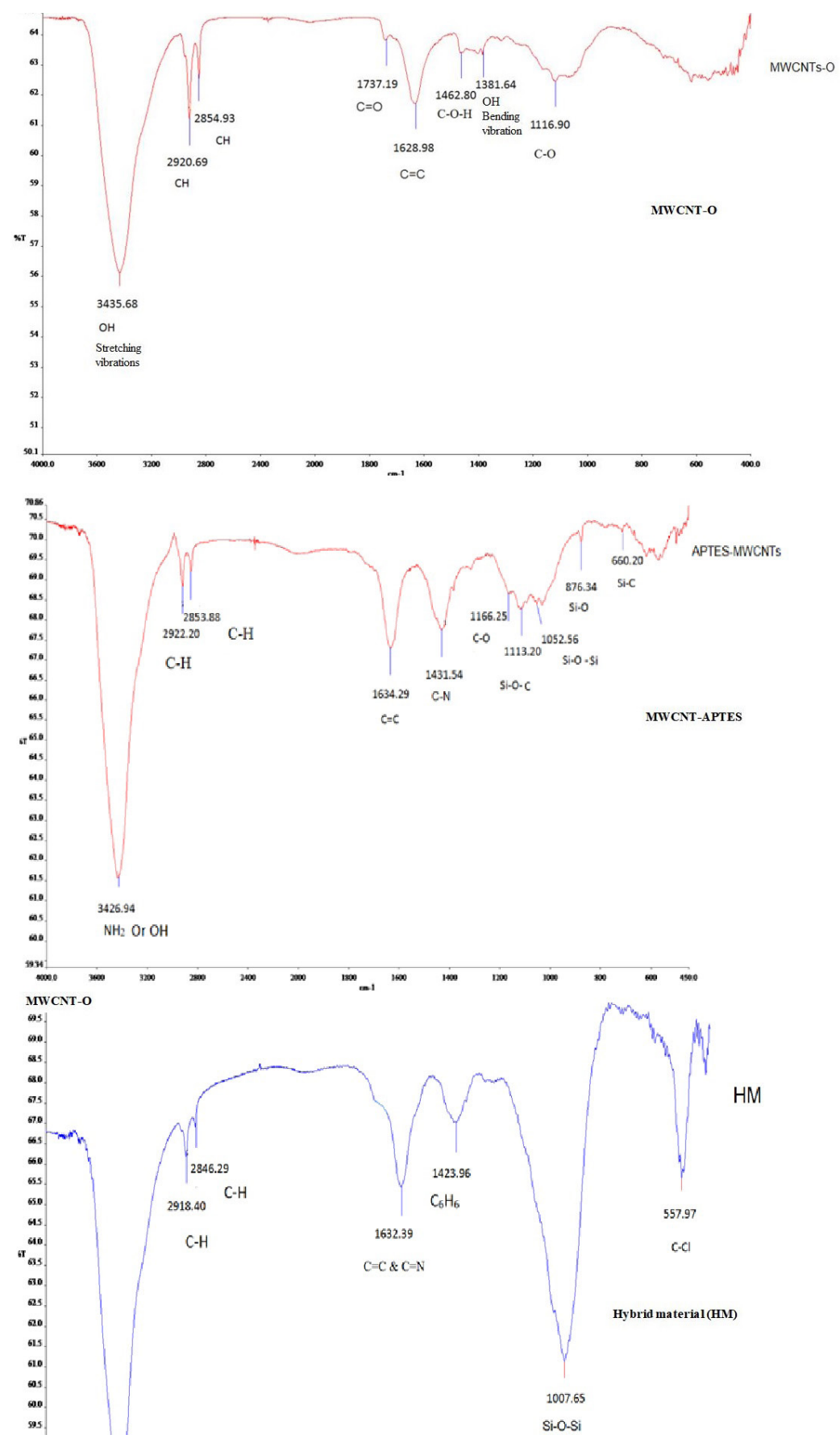

Figure 3. FT-IR spectra of MWCNT-O, APTES-MWCNT and hybrid material (HM).

addition, the band at $1634.29 \mathrm{~cm}^{-1} \mathrm{can}$ be assigned to the $(\mathrm{C}=\mathrm{C})$ stretching in the sample. In the spectrum, there is a shoulder band at $1431.54 \mathrm{~cm}^{-1}$ belonging to the $v(\mathrm{C}-\mathrm{N})$ stretchings [25]. The peaks at 1166.25, 1052.56 and $1130.20 \mathrm{~cm}^{-1}$ assigned to the $v\left(\mathrm{Si}-\mathrm{O}^{-}\right.$ $\mathrm{Si})$ and $v(\mathrm{Si}-\mathrm{O}-\mathrm{C})$ functional groups, respectively [26]. A new peak appeared at $876.34 \mathrm{~cm}^{-1}$ is due to $v(\mathrm{Si}-\mathrm{O}$ or $\mathrm{Si}-\mathrm{OH})$ stretchings confirming silanization reaction [27]. Additionally, in the spectrum, the band at $660.20 \mathrm{~cm}^{-1}$ is due to $v(\mathrm{Si}-\mathrm{C})$ vibration $[28,29]$.FT-IR spectrum of the hybrid material (HM) shows peaks at 557.97 and $1632.39 \mathrm{~cm}^{-1}$ due to the $v(\mathrm{C}-\mathrm{Cl})$ and $v(\mathrm{C}=\mathrm{N})$ vibrations, respectively $[30,31]$. The aldehyde stretching of starting material 3,5-dichlorosalicylaldehyde is absent in the spectrum. The appearance of $v(\mathrm{C}-\mathrm{Cl})$ and $v(\mathrm{C}=\mathrm{N})$ 
stretching bands and absence of aldehyde vibration bands confirm the formation of hybrid material [32]. Additionally, the peak at $1007 \mathrm{~cm}^{-1}$ corresponds to $v(\mathrm{Si}-\mathrm{O}-\mathrm{Si})$ asymmetric stretching vibrations [33] and/or v(C-N) stretching vibrations [34]. Peaks at 2922.20 and $2853.88 \mathrm{~cm}^{-1}$ correspond to stretching of symmetric/asymmetric methylene groups (C$\mathrm{H})$. Bands at $3426.94 \mathrm{~cm}^{-1}$ can be attributed to the stretching vibrations of $\left(-\mathrm{OH}\right.$ and $\left.-\mathrm{NH}_{2}\right)$ [35].

In order to further characterize the samples, Raman spectra were measured. The oxidised MWCNT-O shows two sharp peaks located at 1343.85 and $1536.08 \mathrm{~cm}^{-1}$. The peak at the $1343.85 \mathrm{~cm}^{-1}$ is socalled disorder-induced ( $D$ band) which is belonging to the presence of amorphous of MWCNT sample [36]. The second peak at $1536.08 \mathrm{~cm}^{-1}$ assigned (G band) due to the bond stretching of the (C-C pairs) in the sample [37]. The intensity ratio of $D$ band compared to the $G$ band (ID/IG) is 0.874. The Raman spectrum of APTES-MWCNT shows the $G$ and $D$ band peaks at 1512.03 and $1341.96 \mathrm{~cm}^{-1}$, respectively. The intensity ratio of $D$ band to $G$ band (ID/IG) is 0.887 . The intensity ratio (ID/IG) of APTES-MWCNT is higher than the value off oxidized MWCNT-O suggesting that some multi functionalization are covalently introduced onto the surfaces of MWCNT.

Thermogravimetric analyses (TGA) of MWCNT, MWCNT-O, APTES-MWCNT and hybrid material (HM) were carried out under nitrogen atmosphere in the $20-900^{\circ}$ temperature range with a heating rate of $10^{\circ} \mathrm{C} / \mathrm{min}$. The TGA curves are shown in Figure 5. The starting material MWCNT showed almost no
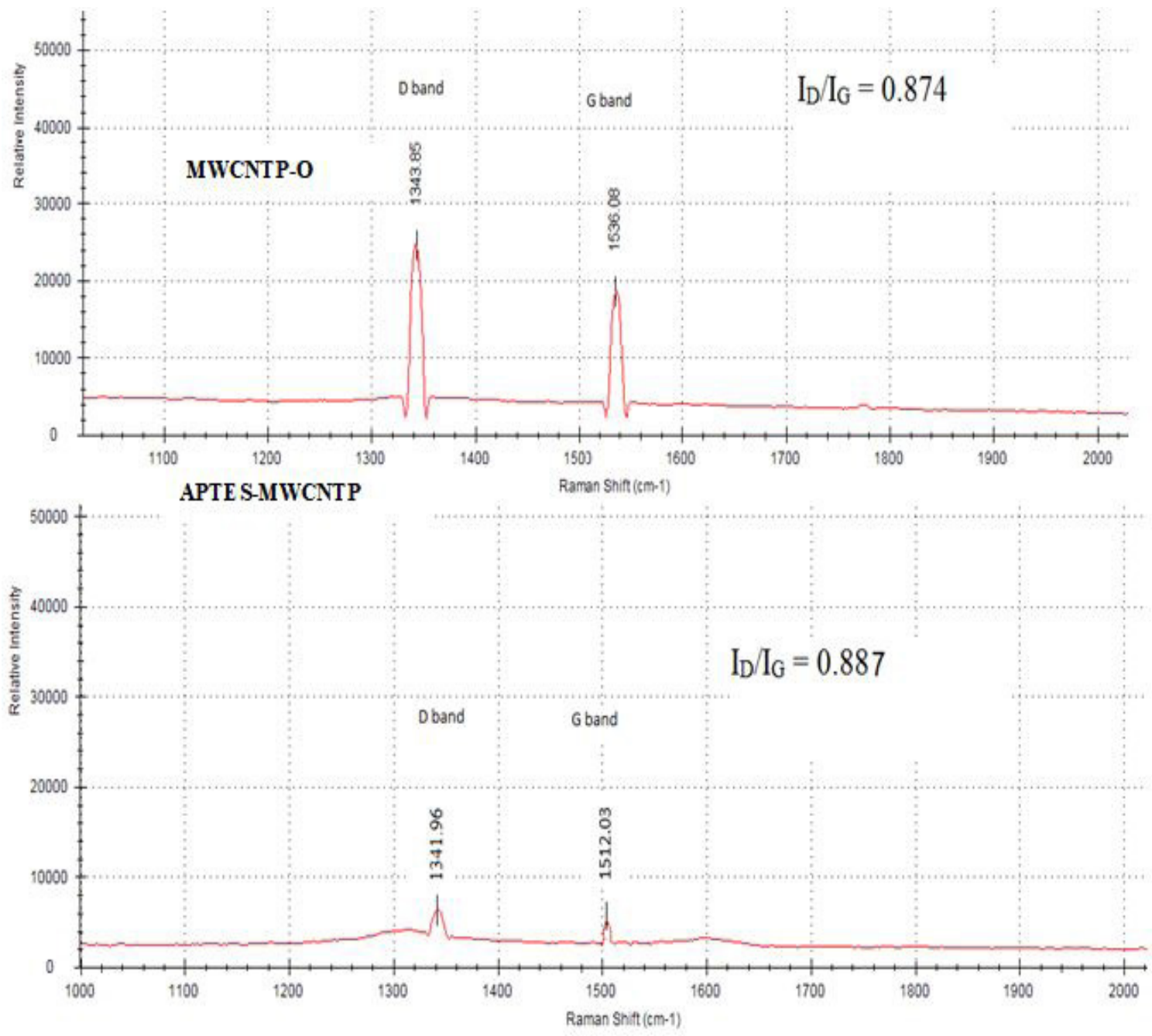

Figure 4. Raman spectra of MWCNT-O and APTES-MWCNT. 


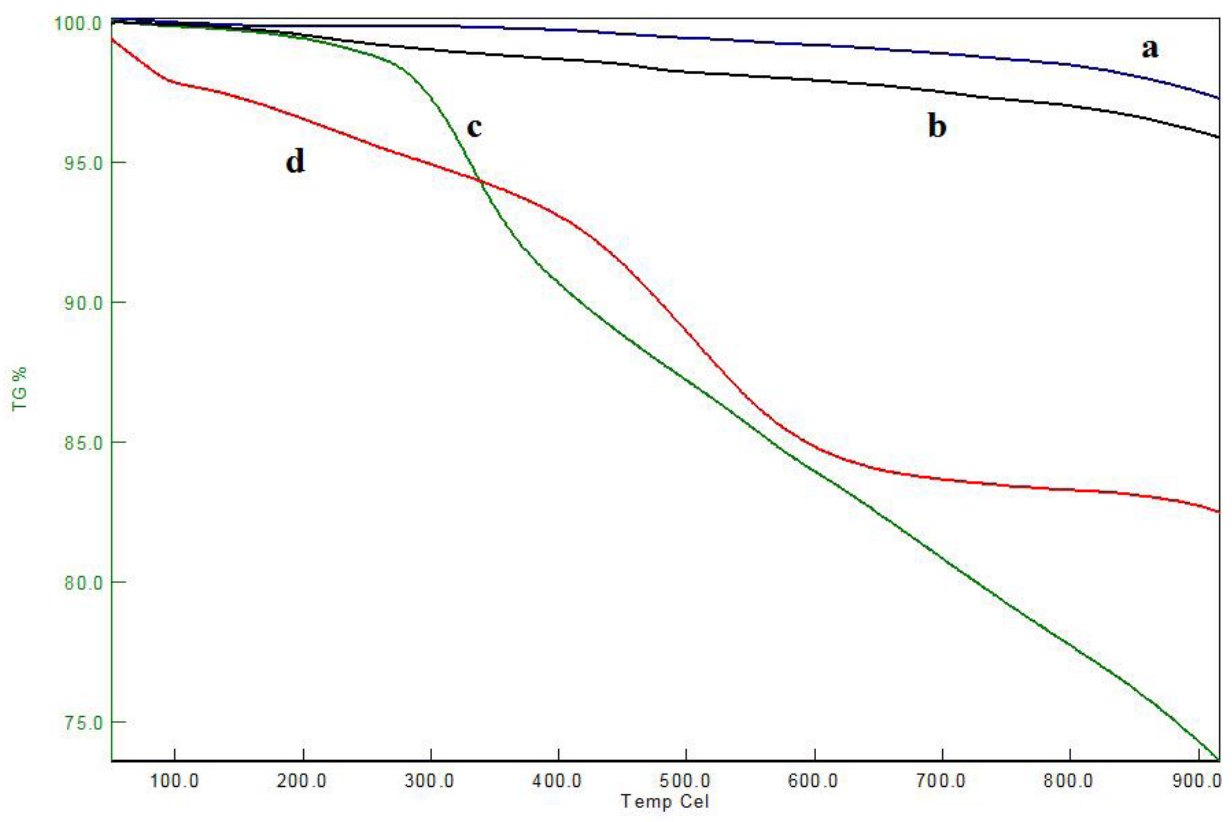

Figure 5. TGA curves of MWCNT (a), MWCNTS-O (b), APTES-MWCNT (c) and HM (d).

decomposition over the temperature range of 20$900^{\circ} \mathrm{C}$ [38]. The oxidized MWCNT-O has lost almost $4 \%$ of the total mass over the temperature range. This mass loss may due the removal of adsorbed water in the sample. The silanized material APTESMWCNT is thermally stable up to $\sim 250{ }^{\circ} \mathrm{C}$. Above $250{ }^{\circ} \mathrm{C}$, the material showed a sharp mass loss and $10 \%$ of total mass was lost in the $250-400{ }^{\circ} \mathrm{C}$ range. The gradual decomposition of the material continued up to $900^{\circ} \mathrm{C}$ and almost $25 \%$ of the mass was lost. The thermal decomposition of APTESMWCNT is mainly due to the removal of organic moiety of APTES in the structure. These results may be assigned to the physical effect such as the silane linking's on surface MWCNT [39]. TGA of hybrid material (HM) started to weigh loss at around $65^{\circ} \mathrm{C}$. The thermal decomposition continued up to $900^{\circ} \mathrm{C}$ and almost $15 \%$ of total mass was lost.

XRD diffraction patterns of MWCNT-O and APTES-MWCNT are shown in Figure 6 . In the spectrum of MWCNT-O two diffraction peaks observed at $26.08^{\circ}$ (inter layer spacing distance between atomic layers in a crystal $3.41 \mathrm{~A}^{\circ}$ ) and $44.78^{\circ}\left(2.02 \mathrm{~A}^{\circ}\right)$ correspond to the (002) and (100) planes of the hexagonal structure [40]. The XRD patterns of the APTES-MWCNT did not change the position of a diffraction peak at $26.08^{\circ}\left(3.41 \mathrm{~A}^{\circ}\right)$ and $44.78^{\circ}\left(2.02 \mathrm{~A}^{\circ}\right)$ (which correspond to the (002) and (001) planes for MWCNT-O. This indicates that the silanized treatment of MWCNTs do not destroy or damaged during the treatment stage and the lattice crystal structure stays reasonable according to XRD patterns [41].

The EDX spectra of the prepared materials are shown in Figure 7. The chemical composition analysis showed carbon and oxygen atoms signals confirming the oxidation of MWCNT. These results are in good agreement with the results obtained in literature [42]. The EDX spectrum of APTESMWCNTs showed large quantities of $C$ and $S i$ atoms and trace quantities of $\mathrm{O}$ and $\mathrm{N}$ atoms. The hybrid material (HM) showed the chemical composition of the material made up of $\mathrm{C}, \mathrm{O}, \mathrm{N}, \mathrm{Si}$ and $\mathrm{Cl}$ atoms confirming the formation of the hybrid material. The presence of $\mathrm{N}$ and $\mathrm{O}$ atoms as functional groups $(\mathrm{O}, \mathrm{N})$ on the surface of the nanotubes plays an important role for the adsorption of heavy metals. SEM images MWCNT-O, APTES-MWCNT and hybrid material (HM) are given in Figure 8. SEM image of MWCNT-O have a rope-like with complicated agglomeration tubes. Upon silanization of MWCNT-O, some bundles appear exfoliated and curled in the 

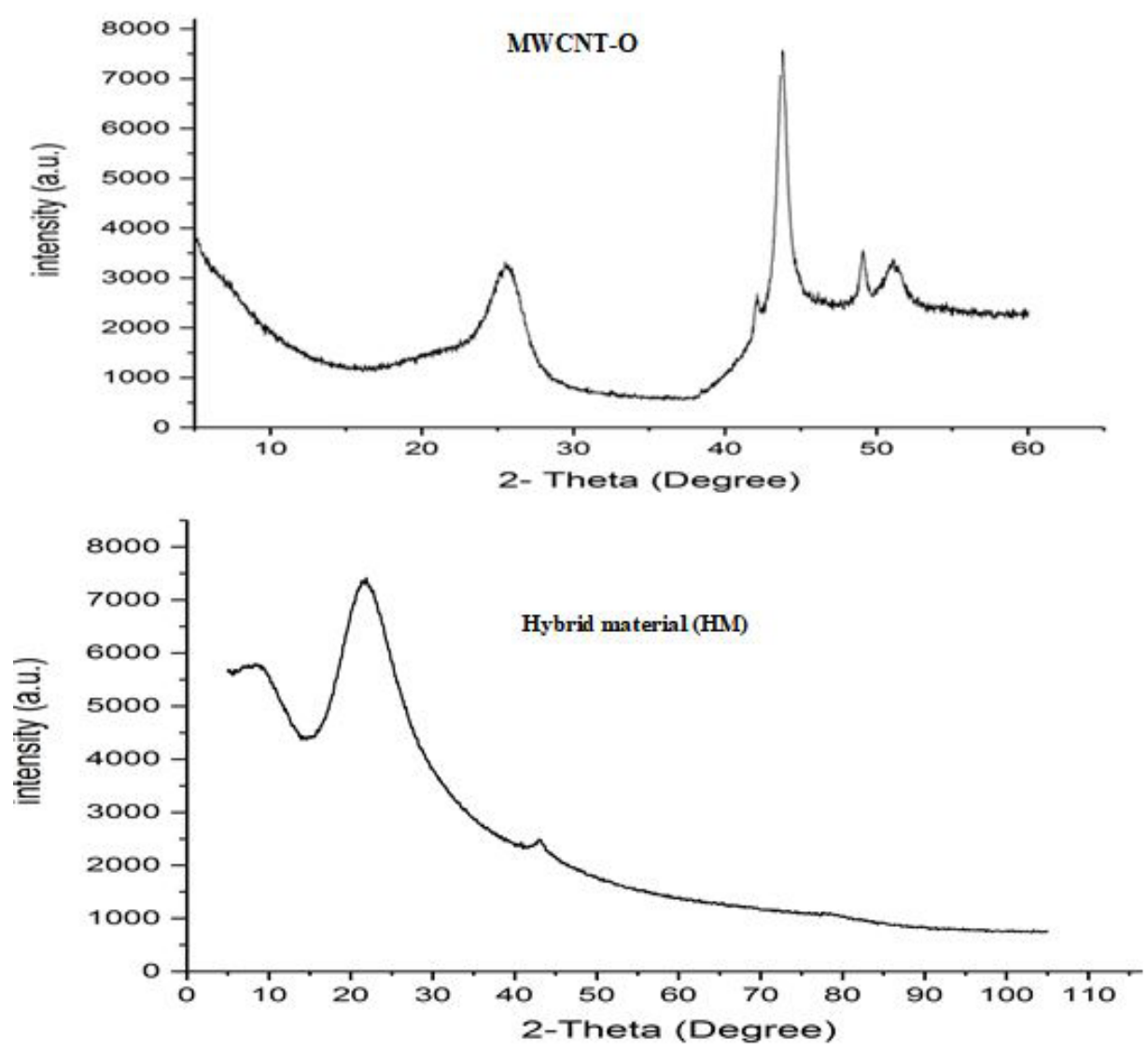

Figure 6. XRD diffraction patterns of MWCNT-O and HM.

SEM image of APTES-MWCNT. Formation of hybrid material (HB) causes to the tubes of shorter length with a large population of unordered sites.

TEM images of MWCNT-O, APTES-MWCNT and hybrid material (HM) were given in Figure 9. In the TEM image of MWCNT-O, the parts of the sheet, particularly the central area, is homogeneous and quite smooth. The imaging of the sheet displays continuous tube patterns and it has the multilayer sheet nature. In the TEM image of the APTESMWCNT, the black dots on the surface can be attributed to the amino silane group. The TEM image of the hybrid material was taken at $100 \mathrm{~nm}$. Hybrid material showed several black aggregations on the surface of the tube may be assigned to the salicylidene moiety.

\section{Adsorption and Desorption Studies}

Adsorption of the $\mathrm{Cu}(\mathrm{II})$ and $\mathrm{Co}(\mathrm{II})$ ions by the new hybrid material from aqueous solution was carried out by using batch experiments. In determining the effect of batch parameters, the stock soluti- ons $1000 \mathrm{mg} / \mathrm{L}$ for $\mathrm{Cu}(\mathrm{II})$ and $\mathrm{Co}(\mathrm{II})$ ions were prepared by dissolving required amount $\mathrm{Cu}\left(\mathrm{CH}_{3} \mathrm{CO}_{2}\right)_{2}$. $\mathrm{H}_{2} \mathrm{O}$ and $\mathrm{Co}\left(\mathrm{NO}_{3}\right)_{2} \cdot 6 \mathrm{H}_{2} \mathrm{O}$ in volumetric flasks. The hybrid material $(25 \mathrm{mg}$ ) was contacted with $25 \mathrm{~mL}$ of $\mathrm{Cu}(\mathrm{II})$ and $\mathrm{Co}(\mathrm{II})$ solutions as initial concentrations $\left(C_{0}\right)\left(\mathrm{mg} \mathrm{L}^{-1}\right)$. After that the hybrid material was removed from adsorption medium by using using $0.45 \mu \mathrm{m}$ membrane filter papers. The amount of $\mathrm{Cu}(\mathrm{II})$ and $\mathrm{Co}(\mathrm{II})$ in the desorption medium was determined by ICP-OES analyses. The amount of metal ion adsorbed on the hybrid material (HM) was determined by the difference of the initial concentration $\left(\mathrm{C}_{0}\right)$ and the final concentration $\left(C_{f}\right)$. The amount of metal ion adsorbed onto HM $(\mathrm{mg} / \mathrm{g})$ was calculated by the following equation:

$$
Q_{e}=\left[\left(C_{0}-C_{f}\right) \cdot V\right] / W
$$

Where $Q_{e}=$ the amount of solute adsorbed from the solution. $V=$ Volume of the adsorbate, $C_{0}=$ the concentration before adsorption, $C_{f}=$ the concentration after adsorption and $\mathrm{W}=$ the weight in gram of the adsorbent. 

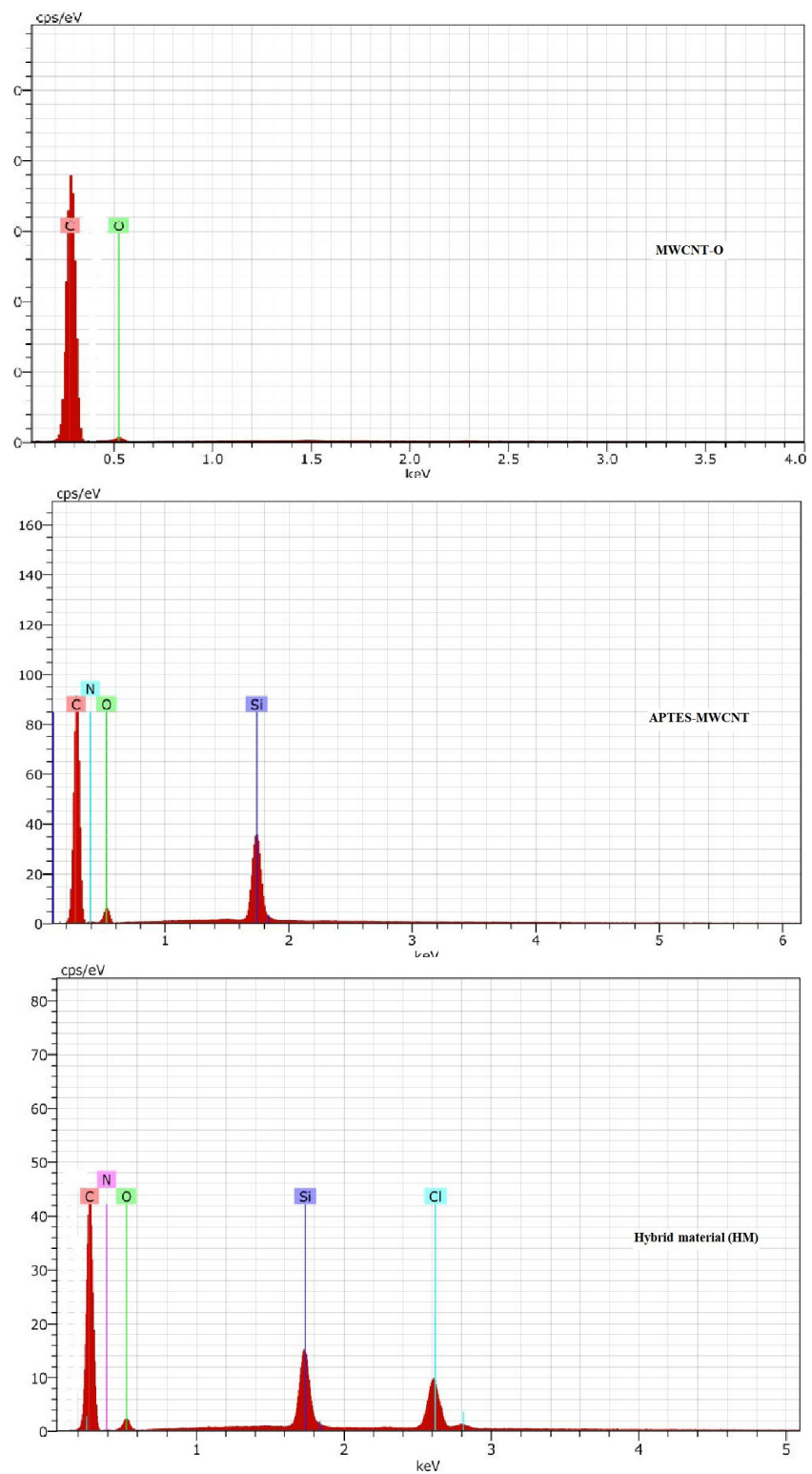

Figure 7. EDX spectra of MWCNT-O, APTES-MWCNT and hybrid material (HM).

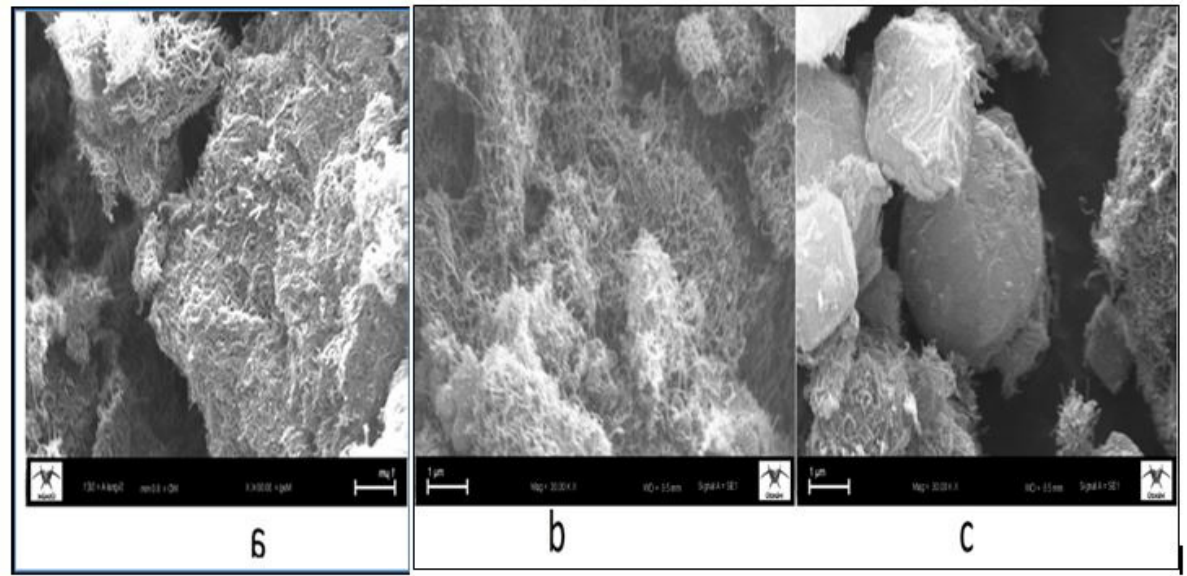

Figure 8. SEM images of MWCNT-O (a), APTES-MWCNT (b) and HM (c). 


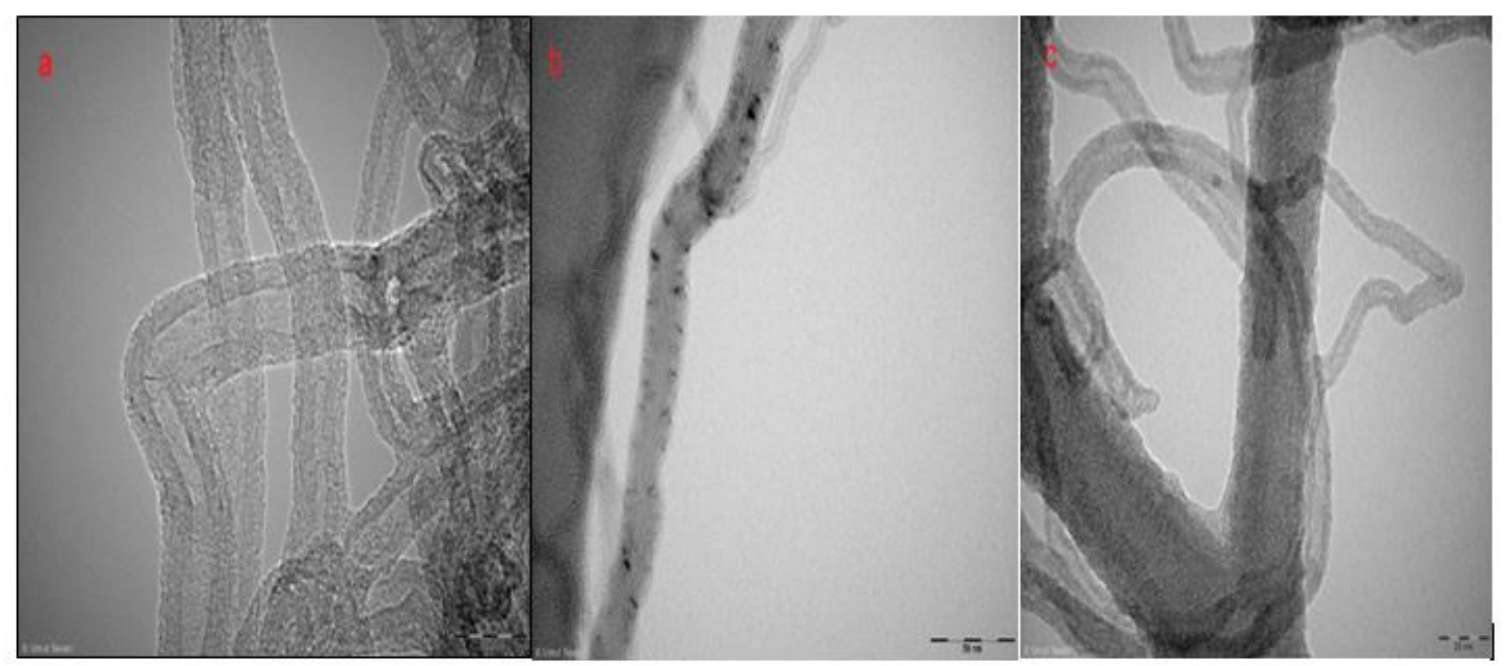

Figure 9. TEM images of MWCNT-O (a), APTES-MWCNT (b) and HM (c).

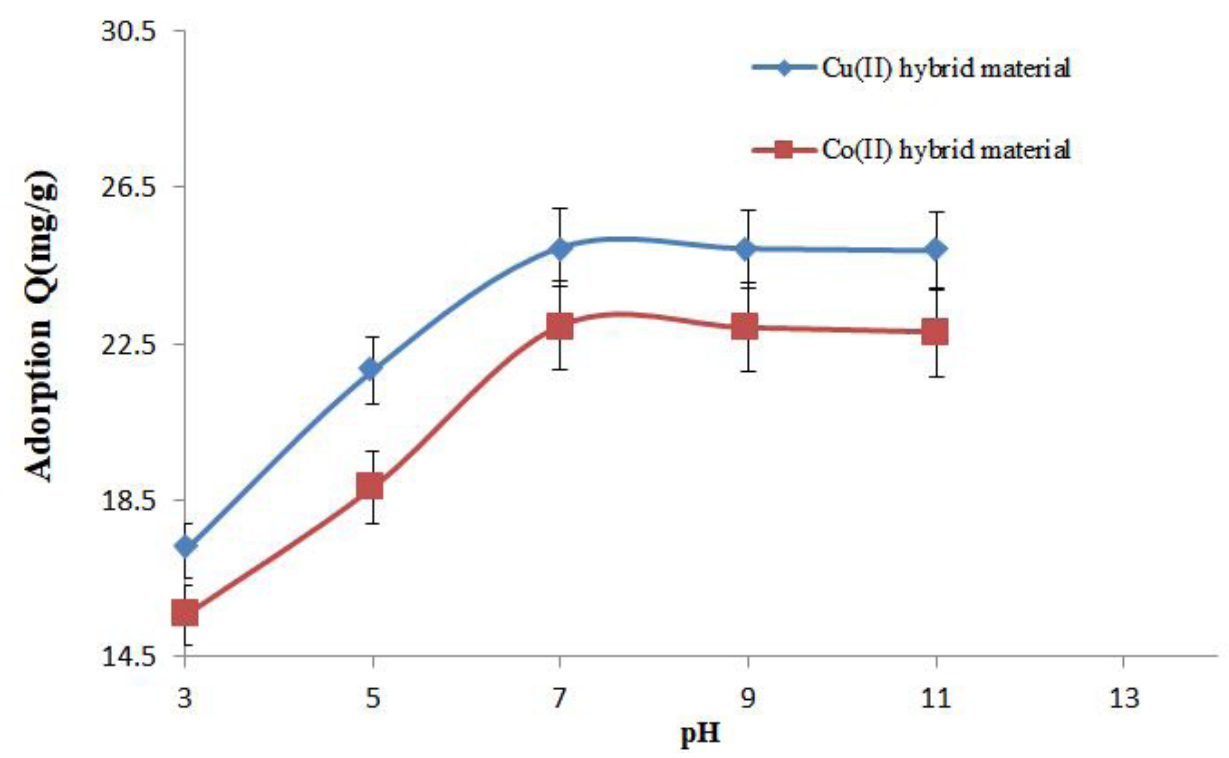

Figure 10. The effect of $\mathrm{pH}$ on adsorption of $\mathrm{Cu}(\mathrm{II})$ and $\mathrm{Co}(\mathrm{II})$ at initial concentration of metal ion is $25 \mathrm{mg} / \mathrm{L}, \mathrm{HM}$ dosage $25 \mathrm{mg}$ and contact time $60 \mathrm{~min}$. Each point is an average of three parallel studies.

The effect of $\mathrm{pH}$, contact time, initial concentration, temperature was studied to determine the optimum conditions.

\section{Effect of pH}

The solution $\mathrm{pH}$ is identified as an important parameter of ion adsorption at the solid-water interfaces. The $\mathrm{pH}$ effects deeply depend on the properties of adsorbent surface such as surfaceactive groups [43]. Effect of $\mathrm{pH}$ in the process of the adsorption of $\mathrm{Cu}(\mathrm{II})$ and $\mathrm{Co}(\mathrm{II})$ ions on hybrid Material was investigated at different $\mathrm{pH}$ values. As shown in Figure 10, the highest absorption was observed at $\mathrm{pH} 7$ and then reaches its equilibrium. In acidic medium, the process of removing ions is much lower compared to removal in basic medium.
Results of previous studies indicated that $\mathrm{H}^{+}$ions stay on the surface resulting in positively charged $\left(\mathrm{H}^{+}\right)$surface of the sorbent; sorption of metal onto the surface of the sorbent may be impeded or prevent because of charge repulsion. With the increase of $\mathrm{pH}$ (basic mediums) the charge on leads to the material surface increase negative charge $\left(\mathrm{H}^{+}\right.$ poor), which causes electrostatic interactions and thus results in higher adsorption of metal species that are favourable for adsorbing cationic species. The maximum adsorption capacity of $\mathrm{Cu}(\mathrm{II})$ and $\mathrm{Co}(\mathrm{II})$ at $\mathrm{pH} 7$ is 24.96 and $22.96 \mathrm{mg} / \mathrm{g}$, respectively. Figure 10 The effect of $\mathrm{pH}$ on adsorption of $\mathrm{Cu}(\mathrm{II})$ and $\mathrm{Co}(\mathrm{II})$ at initial concentration of metal ion is 25 $\mathrm{mg} / \mathrm{L}, \mathrm{HM}$ dosage $25 \mathrm{mg}$ and contact time $60 \mathrm{~min}$. Each point is an average of three parallel studies. 


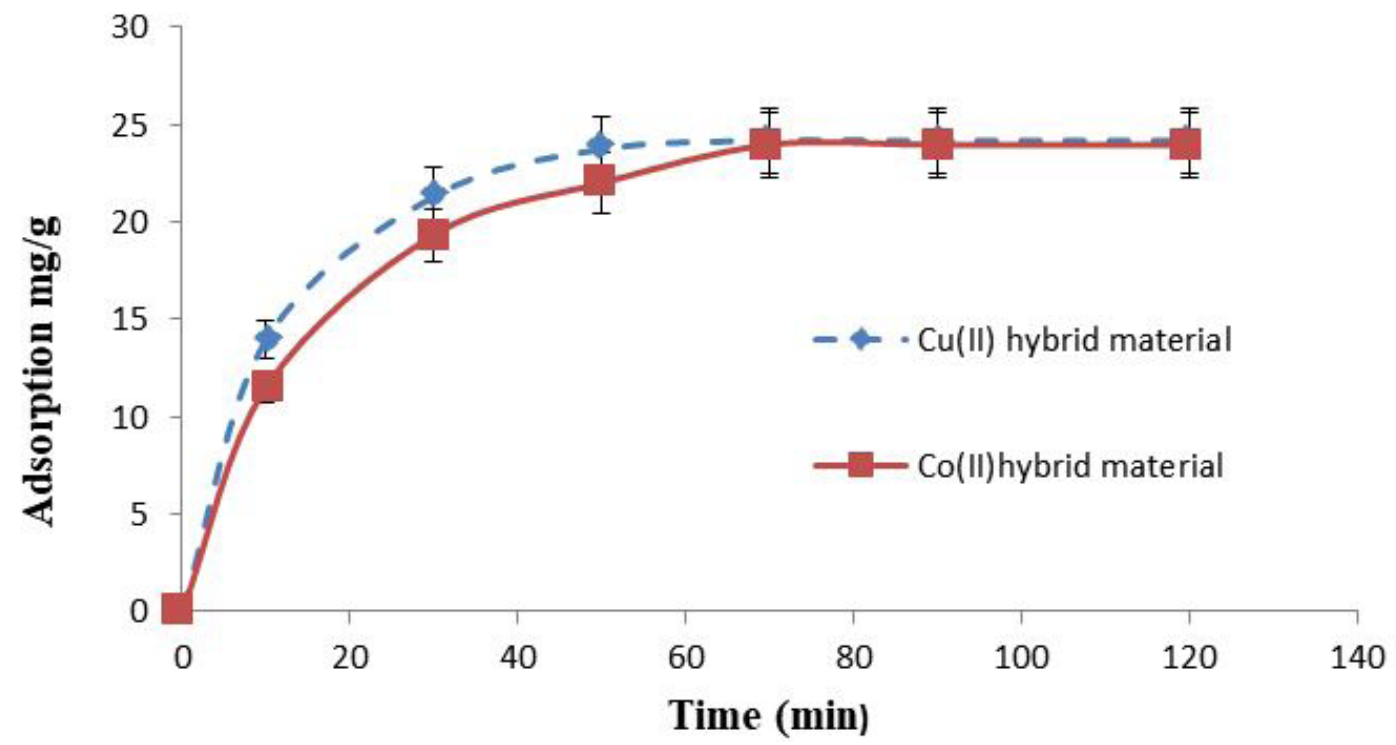

Figure 11. The effect of contact time on adsorption of $\mathrm{Cu}(\mathrm{II})$ and $\mathrm{Co}(\mathrm{II})$ at $25(\mathrm{mg} / \mathrm{L})$, dosage $\mathrm{HM} 25 \mathrm{mg}$, $\mathrm{pH}=7$, constant shaking speed of $250 \mathrm{rpm}$ and $23 \pm 1^{\circ} \mathrm{C}$. Each point is an average of three parallel studies.

\section{Effect of Contact Time}

The effect of contact time on the removal of metal ions $\mathrm{Cu}$ (II) and $\mathrm{Co}$ (II) from aqueous solutions was investigated for hybrid material. Figure 11 shows that the adsorption of both metal ions increased with the increase in contact time. The rate of adsorption is extremely high for the first $10 \mathrm{~min}$ because the adsorption sites are unoccupied and $\mathrm{Cu}(\mathrm{II})$ and $\mathrm{Co}(\mathrm{II})$ can easily interact with these sites. The 24.163 and $23.962 \mathrm{mg} / \mathrm{g}$ adsorptions were seen after $70 \mathrm{~min}$ for $\mathrm{Cu}(\mathrm{II})$ and $\mathrm{Co}(\mathrm{II})$, respectively, and then reaches equilibrium. There is no change in adsorption on further increases in contact time. Adsorbent increased lightly and slowly until reach saturation value and this can be explained on the basis that as initially a large number of vacant surface sites are available for adsorption of metal ions but with passes of time the surface sites become exhausted [44].

\section{Effect of Initial Concentration}

Adsorption of metal ions $\mathrm{Cu}(\mathrm{II})$ and $\mathrm{Co}(\mathrm{II})$ ions on MWCNT-O and hybrid material as a function of $\mathrm{Cu}(\mathrm{II}) / \mathrm{Co}$ (II) initial concentration were investigated. The concentrations in the range from $50 \mathrm{ppm}$ to $600 \mathrm{ppm}$ of the both metal ions have been studied (Figure 10). The adsorption of $\mathrm{Cu}(\mathrm{II})$ and $\mathrm{Co}(\mathrm{II})$ ions on the MWCNTs-O is lower than that of ions on the hybrid material under the same experimental conditions. Surfaces MWCNTs-O contain just oxygen atom containing functional groups, whereas in the hybrid material there are nitrogen and oxygen group containing functional groups on the surfaces. The amount of metal ions adsorbed per unit mass of the hybrid material increased at the beginning with concentration of metal ions then reached an equilibrium value which proposes saturation of active adsorption sites on the surface of the materials. At low concentration the relation of surface active sites to the total metal ions in the solution is high and for this reason every metal ions interact with the adsorbent and are removed rapidly from the solution. The maximum adsorption capacity of MWCNT-O and HM for $\mathrm{Cu}(\mathrm{II})$ ion is 491.902 and $386.773 \mathrm{mg} / \mathrm{g}$ (at 500 $\mathrm{ppm})$, respectively. The maximum capacity of $\mathrm{HB}$ and MWCNT-O for Co(II) ion is 489.688 and 415.61 $\mathrm{mg} / \mathrm{g}$ (at $500 \mathrm{ppm}$ ), respectively. When adsorption values are compared, the hybrid material showed better adsorption behaviors than the oxidized multi-walled carbon nanotube (MWCNT-O).

\section{Effect of Temperature}

Temperature is an important parameter to determine the thermodynamics of the adsorption process. The effect of temperature on the adsorption up take of metal ions ( $\mathrm{Cu}(\mathrm{II})$ and $\mathrm{Co}(\mathrm{II}))$ was investigated for the hybrid material. Six different temperatures were considered in this study $\left(25,30,35,40,50\right.$ and $\left.60^{\circ} \mathrm{C}\right)$. As shown in Figure 13 the adsorption of the metal ions onto $\mathrm{HM}$ remarkably increased with a rise in temperature until $35^{\circ} \mathrm{C}$. However, increasing temperature above $35^{\circ} \mathrm{C}$ adsorption reached equilibrium with 

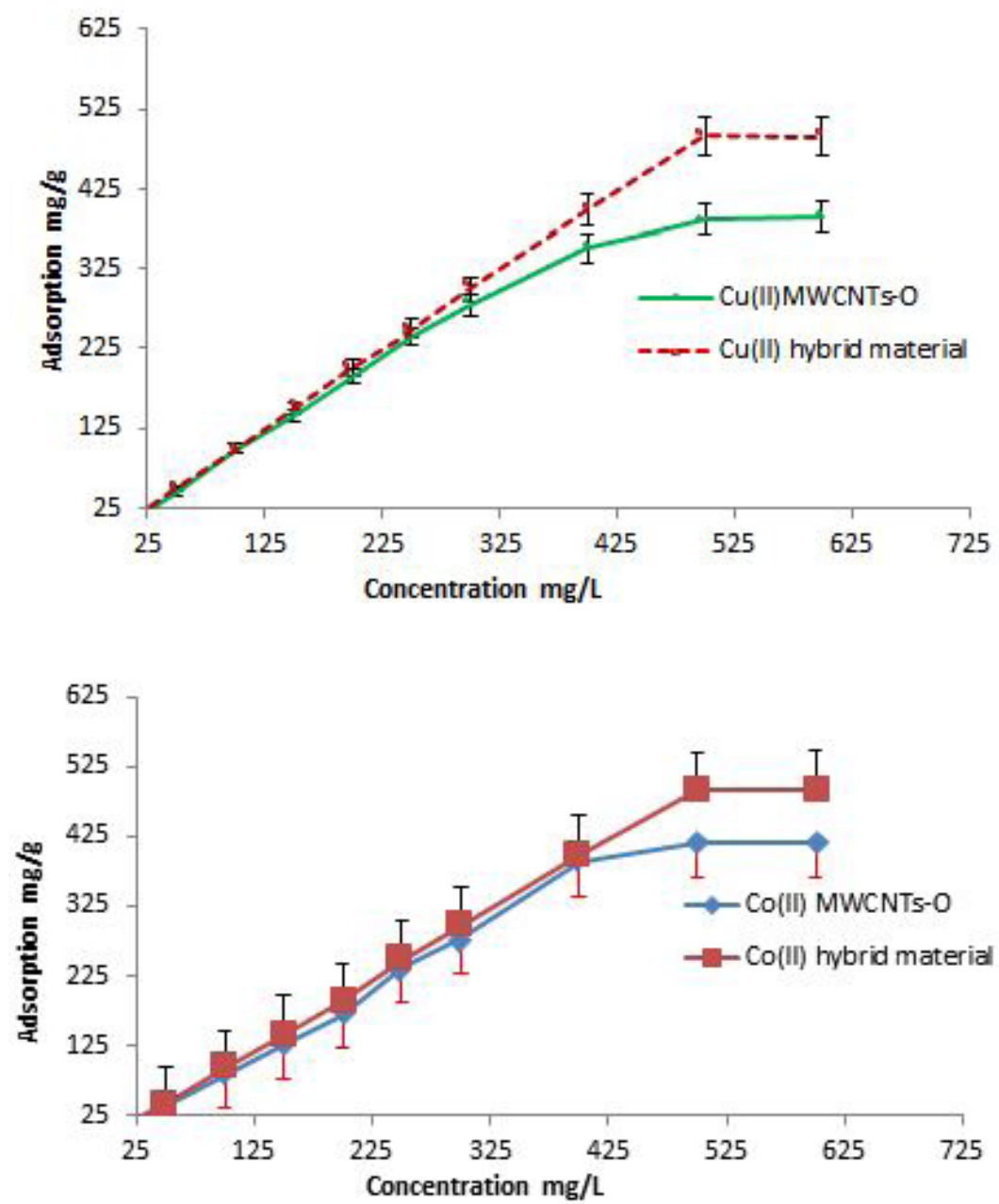

Figure 12. Effect of initial concentrations on removal of $\mathrm{Cu}(\mathrm{II})$ and $\mathrm{Co}(\mathrm{II})$ ions (conditions: HM dosage $25 \mathrm{mg} / \mathrm{L}$, pH 7, contact time $60 \mathrm{~min}$, agitation speed, $250 \mathrm{rpm}$ and temperature: $25^{\circ} \mathrm{C}$ ). Each point is an average of three parallel studies.

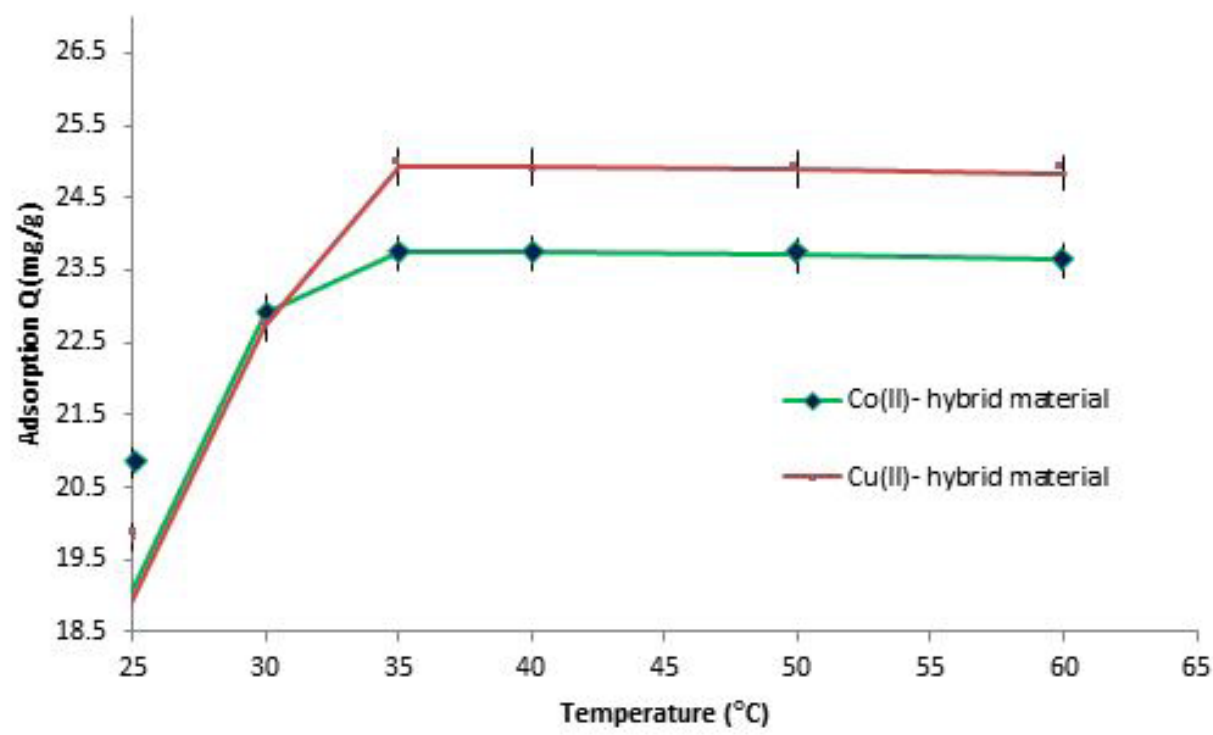

Figure 13. Effect of temperature on adsorption of $\mathrm{Cu}(\mathrm{II})$ and $\mathrm{Co}$ (II) (initial concentration of metal ions is $25 \mathrm{mg} / \mathrm{L}, \mathrm{HM}$ dosage $25 \mathrm{mg}, \mathrm{pH}=7$, constant shaking speed of $250 \mathrm{rpm}$ and contact time $60 \mathrm{~min}$. Each point is an average of three parallel studies). 
very slightly decreased and adsorption does not increase anymore, this can be described by the fact that there are limited numbers of vacancies on the surface of the adsorbent. This process occurred for two reasons; firstly, the adsorbent no more can bind extra ions as the number of sites available on the adsorbent is constant. Next increasing temperature may form an equilibrium between the binding and dissociation of the metal ions. For $\mathrm{Cu}(\mathrm{II})$ and $\mathrm{Co}(\mathrm{II})$, the maximum adsorption capacity was obtained at $35^{\circ} \mathrm{C}$ with adsorption capacities of $24.926 \mathrm{mg} / \mathrm{g}$ and 23.744 $\mathrm{mg} / \mathrm{g}$, respectively.

\section{Conclusion}

In this work, we prepared a new multi-walled carbon nanotube-based hybrid material for the removal of $\mathrm{Cu}(\mathrm{II})$ and $\mathrm{Co}(\mathrm{II})$ ions from aqueous solutions. The hybrid material was obtained in three step reactions. The prepared material was characterized by several spectroscopic and analytical techniques including FT-IR, Raman, UV-Vis spectroscopies, SEM, TEM, EDX, XRD diffraction, TGA studies. The hybrid material was then used as an adsorbent for the removal of $\mathrm{Cu}(\mathrm{II})$ and $\mathrm{Co}(\mathrm{II})$ from aqueous solutions. The adsorption capacity of the hybrid material was measured by ICP-OES analyses. The effect of the parameters such as $\mathrm{pH}$, temperature, initial concentration and contact on the adsorption properties was investigated to find the optimum conditions.

\section{ACKNOWLEDGEMENT}

Authors are thankful to Kahramanmaraş Sutcu Imam University for providing the technical support for this study.

\section{0}

1. R.M. Harrison, Effects and control. Royal Society of Chemistry, Pollution: causes (2001).

2. D.H. Pink, Investing in tomorrow's liquid gold. April 19, (2006).

3. L. West, World water day: a billion people worldwide lack safe drinking water. URL: environment. (2006).

4. T. Satyanarayana, B.N. Johri and A. Prakash eds., Microorganisms in environmental management: microbes and environment. Springer Science \& Business Media 212012 818-820.

5. D.K.V. Ramana, K. Jamuna, B. Satyanarayana, B. Venkateswarlu, M.M. Rao and K. Seshaiah, Removal of heavy metals from aqueous solutions using activated carbon prepared from Cicer arietinum, Toxicological and Environ Chemistry, 928 (2010) 1447-1460.
6. M. Cempel, and G. Nikel, Nickel: A review of its sources and environmental toxicology, Polish Journal of Environmental Studies, 153 (2006) 375-382.

7. J.E. Fergusson, Heavy elements: chemistry, environmental impact and health effects,Pergamon (1990).

8. D.W. Johnson, and R.T.Johnson, Cooperative learning. Blackwell Publishing Ltd.(2008).

9. I.W. Donald, Waste immobilization in glass and ceramic based hosts: radioactive, toxic and hazardous wastes, John Wiley \& Sons.(2010).

10. J.O. Duruibe, M.O. COgwuegbu, and J.N. Egwurugwu, Heavy metal pollution and human biotoxic effects, International Journal of Physical Sciences, 25 (2007) 112-118.

11. W.Li, M.R. Probert,M.Kosa, T.D. Bennett, A. Thirumurugan, R.P.Burwood, M. Parinello, J.A. Howard and A.K. Cheetham, Negative linear compressibility of a metal-organic framework, Journal of the American Chemical Society, 13429 (2012)11940-11943.

12. J.W.S. Hummers and R.E. Offeman, Preparation of graphitic oxide, Journal of the American Chemical Society, 80(6) (1958) 1339-1339.

13. J. Kathi, and K.Y. Rhee, Surface modification of multi-walled carbon nanotubes using 3-aminopropyl triethoxysilane, Journal of Materials Science, 431 (2008)33-37.

14. Z. Luo, and A.T. Johnson, High yield preparation of macroscopic graphene oxide membranes,.Journal of the American Chemical Society 1313, 898-899

15. C. Chen, and X. Wang, Adsorption of Ni (II) from aqueous solution using oxidized multiwall carbon nanotubes, Industrial \& Engineering Chemistry Research, 4526 (2006) 9144-9149.

16. J.Y. Xu, K. Han, S.X. Li , J.S,. Cheng, G.T. Xu, W.X. Li and Q.N. Li, Pulmonary responses to polyhydroxylatedfullerenols, $\mathrm{C} 60(\mathrm{OH}) \mathrm{x}$, Journal of Applied Toxicology, 297 (2009) 578-584.

17. W.M. Davis, C.L. Erickson, C.T. Johnston, J.J. Delfino, and J.E. Porter, Quantitative Fourier Transform Infrared spectroscopic investigation humic substance functional group composition, Chemosphere, 3812 (1999) 2913-2928.

18. F. Avilés, J.V. Cauich-Rodríguez, L.Moo-Tah, A. MayPat, and R. Vargas-Coronado, Evaluation of mild acid oxidation treatments for MWCNT functionalization, Carbon, 4713 (2009) 2970-2975.

19. C. Lu, C. Liu, and G. P.Rao, Comparisons of sorbent cost for the removal of $\mathrm{Ni}^{2+}$ from aqueous solution by carbon nanotubes and granular activated carbon, Journal of hazardous materials, 1511 (2008) 239-246.

20. C. Zhao, L. Ji, H. Liu, G. Hu, S. Zhang, M. Yang, and Z.Yang, Functionalized carbon nanotubes containing isocyanate groups, Journal of Solid State Chemistry, 17712 (2004) 4394-4398.

21. L.H. Teng, IR study on surface chemical properties of catalytic grown carbon nanotubes and nanofibers, Journal of Zhejiang University science A, 95 (2008) 720-726.

22. G. Ovejero, J.L. Sotelo, M.D. Romero, A. Rodríguez, M.A. Ocana, G. Rodríguez, and J. Garcia, Multiwalled Carbon Nanotubes for Liquid-Phase Oxidation. Functionalization, Characterization, and Catalytic Activity, Ind. Eng. Chem. Res., 457 (2006)2206-2212. 
23. Z. Zhao, Z. Yang, Y. Hu, J. Li, and X. Fan, Multiple functionalization of multi-walled carbon nanotubes with carboxyl and amino groups, Applied surface science, 276 (2013) 476-481.

24. P.C. Ma, J.K. Kim, and B.Z. Tang, Functionalization of carbon nanotubes using a silanecoupling agent, Carbon, 4415 (2006)3232-3238.

25. H. Gaspar, C. Pereira, S.L.H. Rebelo, M.F.R. Pereira, J.L. Figueiredo, and C. Freire,. Understanding the silylation reaction of multi-walled carbon nanotubes, Carbon, 49 11 (2011) 3441-3453.

26. C. Velasco-Santos, A.L. Martinez-Hernandez, W. Brostow, and V.M. Castano, Influence of silanization treatment on thermomechanical properties of multiwalled carbon nanotubes: poly (methylmethacrylate) nanocomposites. Journal of Nanomaterials, (2011), doi:10.115/2011/928659

27. C. Velasco-Santos, A.L. Martinez-Hernandez, M. Lozada-Cassou, A. Alvarez-Castillo, and V.M. Castano, Chemical functionalization of carbon nanotubes through an organosilane, Nanotechnology, 134 (2002) 495.

28. M. Aizawa, and M.S. Shaffer,Silylation of multi-walled carbon nanotubes, Chemical physics letters, 3681 (2003) 121-124.

29. D.S. Bag, R. Dubey, N. Zhang, J. Xie, V.K. Varadan, D. Lal, and G.N. Mathur,. Chemical functionalization of carbon nanotubes with 3-methacryloxypropyltrimethoxysilane (3-MPTS), Smart materials and structures, 135 (2004) 1263.

30. J. Chen, M.A. Hamon, H. Hu, Y. Chen, A.M. Rao, P.C. Eklund, and R.C. Haddon, Solution properties of singlewalled carbon nanotubes, Science, 2825386 (1998) 95-98.

31. O. Eren, N. Ucar, A. Onen, N. Kızıldag, O.F. Vurur, N. Demirsoy, and I. Karacan, Effect of aminefunctionalized carbon nanotubes on the properties of CNT-PAN composite nanofibers. Int. J. Chem. Nuclear Metallurgical Mater Eng., 8(8) (2014) 726-8.

32. C.G. Salzmann, S.A. Llewellyn, G. Tobias, M.A. Ward, Y. Huh, and M.L. Green, The Role of Carboxylated Carbonaceous Fragments in the Functionalization and Spectroscopy of a Single-Walled Carbon-Nanotube Material, Advanced Materials, 196 (2007) 883-887.

33. J.S. Santos, L.S. Teixeira, W.N. Dos Santos, V.A. Lemos, J.M. Godoy, and S.L. Ferreira, Uranium determination using atomic spectrometric techniques: an overview, Analytica chimica acta, 6742 (2010) 143-156.

34. F.V. Ferreira, L. Cividanes, F.S. Brito, B.R.C. de Menezes, W. Franceschi, E.A.N. Simonetti, and G.P. Thim, Functionalizing Graphene and Carbon Nanotubes A Review, Springer.(2016) ISSN: 2191-530X
35. K.T. Shalumon, K.H. Anulekha, C.M. Girish, R. Prasanth, S.V. Nair, and R. Jayakumar, Single step electrospinning of chitosan/poly (caprolactone) nanofibers using formic acid/acetone solvent mixture, Carbohydrate Polymers, 802 (2010) 413-419.

36. I.D. Rosca, F. Watari, M. Uo, and T. Akasaka, Oxidation of multiwalled carbon nanotubes by nitric acid, Carbon, 4315 (2005) 3124-3131.

37. L. Stobinski, B. Lesiak, L. Kövér, J. Tóth, S. Biniak, G. Trykowski, and J. Judek, Multiwall carbon nanotubes purification and oxidation by nitric acid studied by the FTIR and electron spectroscopy methods, Journal of Alloys and Compounds, 5011 (2010) 77-84.

38. D. Bom, R. Andrews, D. Jacques, J. Anthony, B. Chen, M.S. Meier, and J.P. Selegue, Thermogravimetric analysis of the oxidation of multiwalled carbon nanotubes: evidence for the role of defect sites in carbon nanotube chemistry, Nano Letters, 26 (2002) 615-619.

39. J.Y. Kim, and S.H. Kim, Influence of multiwall carbon nanotube on physical properties of poly (ethylene 2, 6-naphthalate) nanocomposites, Journal of Polymer Science Part B: Polymer Physics, 447 (2006) 10621071

40. V.K. Gupta, S. Agarwal, and T.A. Saleh, Chromium removal by combining the magnetic properties of iron oxide with adsorption properties of carbon nanotubes. Water research, 456 (2011) 2207-2212.

41. B. Sharma, R. Chhibber, and R. Mehta, Effect of surface treatment of nanoclay on the mechanical properties of epoxy/glass fiber/clay nanocomposites, Composite Interfaces, 237 (2016) 623-640.

42. T.A. Saleh, The role of carbon nanotubes in enhancement of photocatalysis. Syntheses and Applications of Carbon Nanotubes and Their Composites (2013) doi: 10.5772/51050.

43. J. Zhang, P. Yedlapalli, and J.W. Lee, Thermodynamic analysis of hydrate-based pre-combustion capture of $\mathrm{CO}_{2}$, Chemical Engineering Science, 6422 (2009) $4732-4736$

44. S.Yang, J.Li, D.Shao, J. Hu, and X.Wang, Adsorption of $\mathrm{Ni}$ (II) on oxidized multi-walled carbon nanotubes: effect of contact time, $\mathrm{pH}$, foreign ions and PAA, Journal of hazardous materials, 1661 (2009) 109-116. 